Mateusz Kuczyk

Piotr Jędrzejewski

Pawet Zaluski

Politechnika Gdańska

\title{
The construction of suspended rail vehicle bogie
}

\section{Budowa wózka podwieszanego pojazdu szynowego}

\begin{abstract}
The main topic of this article is the construction of a railway bogie, which was used in authors concept of suspended rail vehicle. Firstly, the vehicle was briefly described with particular consideration of the parameters determining the bogie design. Subsequently, constructional solutions were described in terms of individual bogie subassemblies, like: wheelsets, bogie frame, two stage suspension, propulsion and brake systems. This article is based on authors' master thesis: "The concept of suspended railway engine wagon”, conducted on Mechanical Engineering Faculty of Gdansk University of Technology.
\end{abstract}

Niniejsza publikacja została poświęcona szczegółowemu opisowi wózka, przeznaczonego do wykorzystania w proponowanej przez autorów koncepcji podwieszanego pojazdu szynowego. $W$ pierwszej kolejności skrótowo opisano rzeczony pojazd, ze szczególnym naciskiem na parametry determinujace konstrukcje wózków. Następnie zostały omówione zastosowane rozwiazania konstrukcyjne $w$ zakresie budowy poszczególnych podzespołów wózka, takich jak: zestawy kolowe, rama, dwustopniowe usprężynowanie, układ napędowy i hamulcowy. Artykut ten powstat na podstawie pracy dyplomowej pt. „Koncepcja wagonu silnikowego kolei podwieszanej", na wydziale Mechanicznym Politechniki Gdańskiej.

Keywords: bogie construction, monorail, urban transport

Stowa kluczowe: budowa wózka, kolej jednoszynowa, transport miejski

\section{INTRODUCTION}

A suspended monorail is an alternative solution to subway in medium-sized agglomerations. It is characterised by the following benefits: relatively low cost and time of construction, full independence from the traffic, small use of land area and easy implementation of autonomous systems. Of course this type of transport has also some drawbacks, e.g. absolute incompatibility with other means of transport or the limitations in a route selection caused by a dense city infrastructure. There are only two suspended monorail systems in use: Eugen Langen (Schwebebahn in Germany city of Wuppertal) and SAFEGE (Shonan and Chiba monorail in Japanese Tokyo agglomeration). In the first one a vehicle is suspended asymmetrically under the bogies that consist of two double flanged steel wheels that are mounted in one line and work with a single rail. In SAFEGE system a car body is suspended symmetrically and the bogies move inside the guideway beam and use a set of propulsion and guiding wheels with rubber tires. The first one are responsible for carrying the weight of the vehicle and transmission of traction and braking forces. The second type of wheels ensure that appropriate trajectory is maintained (Fig. 1). More information about sus-

\section{WSTĘP}

Kolei podwieszana stanowi alternatywne rozwiązanie dla metra w średniej wielkości aglomeracjach miejskich. Charakteryzują ją następujące zalety: stosunkowo niski koszt i krótki czas budowy, całkowita niezależność od ruchu ulicznego, wykorzystanie niedużej powierzchni gruntu, łatwość implementacji systemu autonomicznego. Oczywiście rozwiązania tego typu nie są pozbawione wad, takich jak np. całkowita niekompatybilność z innym środkami transportu, czy ograniczenie $\mathrm{w}$ wyborze trasy spowodowane gęstą infrastrukturą naziemną miast. Na świecie można wyróżnić dwa podstawowe systemy kolei podwieszanej: Eugen Langen (Schwebebahn w Niemieckim mieście Wuppertal) i SAFEGE (Shonan i Chiba monorail znajdujące się w japońskiej aglomeracji Tokio). W pierwszym z nich pojazd zawieszony jest asymetrycznie pod wózkami składającymi się z dwóch stalowych kół o podwójnym obrzeżu, które są ustawione w jednej linii i współpracują z pojedynczą szyną. Z kolei w systemie SAFEGE pudło wagonu zawieszone jest symetrycznie, a wózki poruszające się wewnątrz drążonej belki jezdnej, wykorzystują zespoły ogumionych kół jezdnych i prowadzących. Zadaniem tych pierwszych jest utrzymanie masy pojazdu i przenoszenie sił 
pended monorail existing solutions, and proposed vehicle concept, can be find in authors' earlier publications [1] and [2].

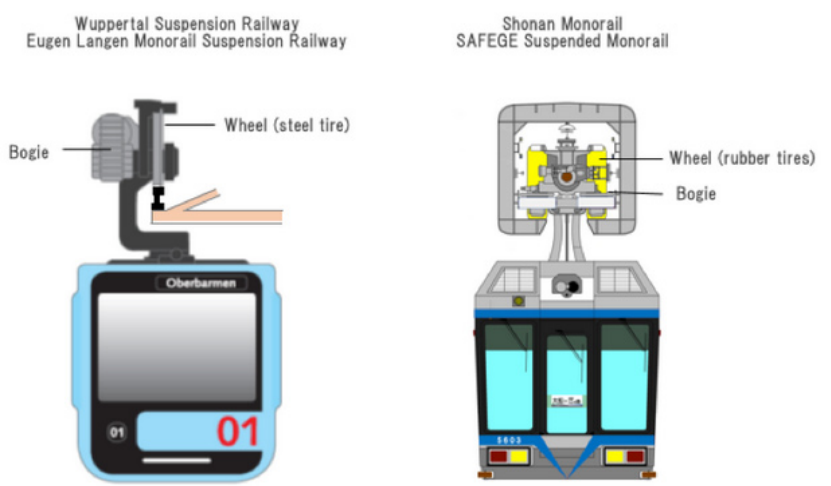

Fig. 1. Comparison of two existing suspended railway systems [3] Rys. 1. Porównanie istniejących systemów kolei podwieszanej [3]

2. GENERAL DESCRIPITON OF THE VEHICLE The solution proposed by the authors is based on a synthesis of the two aforementioned systems. The vehicle is suspended symmetrically under the guideway beam which accommodates two rails of known track gauge. This approach ensures protection of a wheel-rail contact area from weather conditions which results in a stable, high value of adhesion coefficient and allows higher driving/operational safety. A three-section rail vehicle was designed as a part of the thesis (Fig. 2) and selected technical data is presented in Table 1 [4].

Design assumptions, other than urban allocation of the vehicle, are also the ability to move on a track with significant angle of inclination and reaching a speed over $50 \mathrm{~km} / \mathrm{h}$. These requirements had considerable impact on the bogie construction because in order to fulfil them a high-power electric motor was used in conjunction with a reduction gearbox that has a gear ratio. Additionally urban use of the vehicle results in the bogies that are suitable for moving in tight curves and ensuring a reduction of noise and vibration. Another limitation was the requirement to achieve the lowest possible weight of the vehicle, including bogies, which was particularly important when considering infrastructure's strength of material (especially the

Table 1 Technical specification of suspended EMU

\begin{tabular}{|l|c|c|}
\hline Feature & Unit & Value \\
\hline Overall length & $\mathrm{mm}$ & 32580 \\
\hline Width of the vehicle car body & $\mathrm{mm}$ & 2500 \\
\hline Height of the vehicle car body & $\mathrm{mm}$ & 3025 \\
\hline Empty carriage mass & $\mathrm{kg}$ & 43611 \\
\hline Maximum vehicle mass & $\mathrm{kg}$ & 71811 \\
\hline Total capacity & - & 376 \\
\hline Seating capacity & - & 80 \\
\hline Standing capacity & - & 296 \\
\hline Maximum speed & $\mathrm{km} / \mathrm{h}$ & 70 \\
\hline Axle arrangement & - & $1 \mathrm{~A}^{\prime}+1 \mathrm{~A}^{\prime}+1 \mathrm{~A}^{\prime}$ \\
\hline Starting acceleration & $\mathrm{m} / \mathrm{s}^{2}$ & 1,30 \\
\hline Ending acceleration & $\mathrm{m} / \mathrm{s}^{2}$ & 0,45 \\
\hline Maximum braking deceleration & $\mathrm{m} / \mathrm{s}^{2}$ & 3,60 \\
\hline
\end{tabular}

trakcyjnych, a drugie zapewniają utrzymanie odpowiedniego toru ruchu (rys. 1). Szczegółowy opis istniejących rozwiązań, jak również proponowanego pojazdu kolei podwieszanej można znaleźć we wcześniejszych publikacjach autorów: [1] i [2].

\section{OGÓLNY OPIS POJAZDU}

Rozwiązanie proponowane przez autorów opiera się na syntezie obu wspomnianych systemów, a więc pojazd podwieszony jest symetrycznie poniżej belki jezdnej, w której została umieszczona para szyn o zadanym rozstawie. Takie podejście umożliwiło ochronę obszaru współpracy koło-szyna przed warunkami atmosferycznymi, a więc uzyskanie stabilnej, wysokiej wartości współczynnika przyczepności oraz pozwoliło na zwiększenie ogólnie rozumianego bezpieczeństwa jazdy. $W$ ramach pracy przygotowano model trójczłonowego pojazdu szynowego (rys. 2), a jego wybrane dane techniczne zostały zestawione $\mathrm{w}$ tabeli 1 [4].

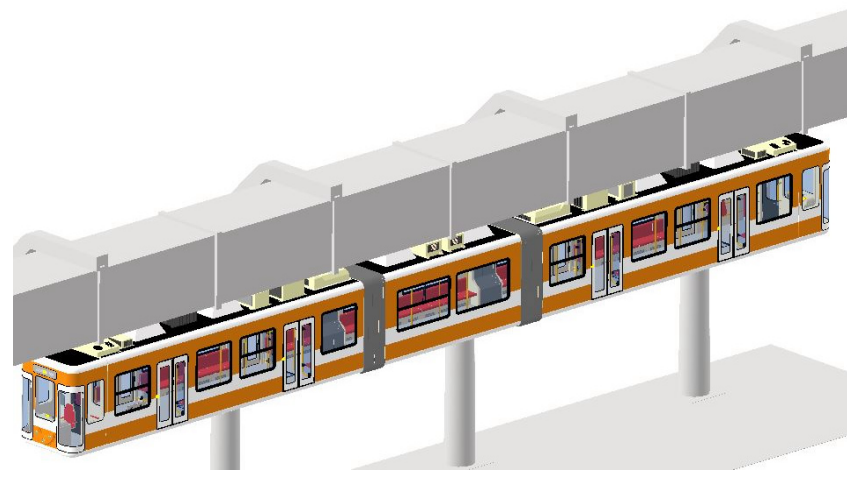

Fig. 2. A view of proposed suspended rail vehicle [4]

Rys. 2. Widok proponowanego pojazdu kolei podwieszanej [4]

Do założeń projektowych, oprócz wspomnianego już miejskiego przeznaczenia pojazdu, należało również pokonywanie toru o znacznym kącie nachylenia oraz osiaganie prędkość powyżej $50 \mathrm{~km} / \mathrm{h}$. Założenia te miały znaczny wpływ na konstrukcję wózka, poprzez konieczność zastosowania silnika elektrycznego dużej mocy oraz redukcyjnej przekładni mechanicznej o wysokim przełożeniu. Dodatkowo miejskie przeznaczenie pojazdu sprawiło, że wózki powinny być przystosowane do ruchu po stosunkowo krętych trasach oraz zapewniać jak najniższą emisję dźwięku czy drgań. Kolejne ograniczenie stanowił wymóg zachowania możliwie niskiej masy pojazdu, w tym wózków, szczególnie istotny z punktu widzenia wytrzymałości infrastruktury, zwłaszcza belki jezdnej. Ważnym aspektem było również zapewnienie możliwie wysokiego komfortu podróżowania.

Oczywistym jest, że wózki poruszające się wewnątrz belki jezdnej definiują jej wymiary gabarytowe (rys. 3), a więc wózek powinien charakteryzować się możliwie kompaktową konstrukcją, w szczególności odnosi się to do jego całkowitej szerokości. 
guideway beam). An important factor was also to ensure the highest possible travelling comfort.

It is obvious that bogies moving inside the guideway beam define its overall dimensions (Fig. 3) so the bogie should be as compact as it is possible. The bogie's total width is particularly important.

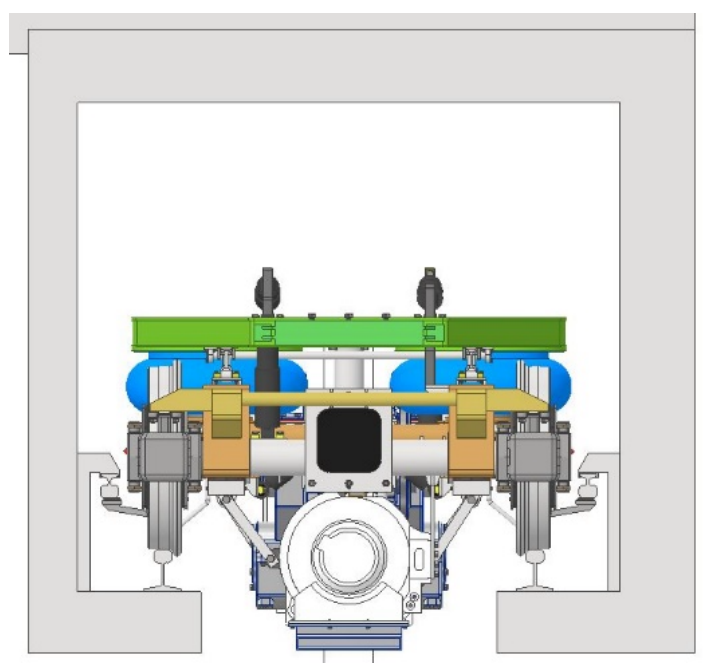

Fig. 3. Rail vehicle bogie in a guideway beam [4]

Rys. 3. Wózek umiejscowiony wewnątrz belki jezdnej [4]

\section{BOGIE CONSTRUCTION}

Designed bogie has only one powered axle which is dictated by limited space that is a result of a short wheelbase. The aim of the wheelbase minimalization is to reduce lateral forces that transfer to wheelsets in track curves. It results in: reduced wheel and rail wear, decreased derailment risk (Nadal criterion - reduction of lateral to vertical force ratio) and bogie weight reduction $[5,6]$. A high-gear ratio gearbox which has substantial dimensions is another impediment that prevents driving both axles. Aforementioned limitations cause an unusual axle arrangement. Another key feature of the bogie is the application of the internal frame which results in a reduced bogie weight and a relatively small width. Travel comfort is provided by a two-stage suspension. The main view of the bogie is presented in Fig. 4 in two variants: with and without suspension frame that is used for mounting car body, so as an integral part of it moves relatively to the bogie. As a result it is an anchor point for the centre pivot and some dampers. Selected technical data is presented in Table 2 [4].

Table 2 Technical specification of vehicle bogie

\begin{tabular}{|l|c|c|}
\hline Feature & Unit & Value \\
\hline Track gauge & $\mathrm{mm}$ & 1435 \\
\hline Length & $\mathrm{mm}$ & 2926 \\
\hline Width & $\mathrm{mm}$ & 1789 \\
\hline Height & $\mathrm{mm}$ & 1151 \\
\hline New wheel diameter & $\mathrm{mm}$ & 750 \\
\hline Worn wheel diameter & $\mathrm{mm}$ & 700 \\
\hline Pressure of the wheelset on a track & $\mathrm{t}$ & 11,97 \\
\hline
\end{tabular}

Tabela 1 Wybrane dane techniczne podwieszanego EZT

\begin{tabular}{|l|c|c|}
\hline Cecha & Jednostka & Wartość \\
\hline Długość całkowita & $\mathrm{mm}$ & 32580 \\
\hline Szerokość pudła wagonu & $\mathrm{mm}$ & 2500 \\
\hline Wysokość pudła wagonu & $\mathrm{mm}$ & 3025 \\
\hline Masa własna pojazdu & $\mathrm{kg}$ & 43611 \\
\hline Dopuszczalna masa całkowita & $\mathrm{kg}$ & 71811 \\
\hline Całkowita liczba miejsc & - & 376 \\
\hline Liczba miejsc siedzących & - & 80 \\
\hline Liczba miejsc stojących & - & 296 \\
\hline Prędkość maksymalna & $\mathrm{km} / \mathrm{h}$ & 70 \\
\hline Układ osi & - & $1 \mathrm{~A}^{\prime}+1 \mathrm{~A}^{\prime}+1 \mathrm{~A}^{\prime}$ \\
\hline Przyspieszenie pocz. rozruchu & $\mathrm{m} / \mathrm{s}^{2}$ & 1,30 \\
\hline Przyspieszenie końca rozruchu & $\mathrm{m} / \mathrm{s}^{2}$ & 0,45 \\
\hline Opóźnienie hamowania maks. & $\mathrm{m} / \mathrm{s}^{2}$ & 3,60 \\
\hline
\end{tabular}

\section{BUDOWA WÓZKA}

Cechą charakterystyczną zaprojektowanego wózka jest posiadanie wyłączenie jednej osi napędnej, co zostało podyktowane znacznym ograniczeniem dostępnej przestrzeni wynikającym z jego krótkiej bazy. Minimalizacja rozstawu osi w wózku ma na celu ograniczenie wartości poprzecznych sił prowadzących oddziałujących na zestawy kołowe w czasie pokonywania łuków torowych. Pozwala to na: ograniczenie zużycia kół i szyn, zwiększenie bezpieczeństwa przed wykolejeniem (kryterium Nadala - zmniejszenie stosunku siły poprzecznej do siły pionowej) oraz zmniejszenie masy całkowitej wózka $[5,6]$. Dodatkowym utrudnieniem, skutecznie uniemożliwiającym napędzanie obu osi, była konieczność zastosowania przekładni o dużym przełożeniu, a więc i wymiarach zewnętrznych. Z powyżej opisanych przyczyn w pojeździe zastosowano dość nietypowy układ osi. Kolejną cechą charakterystyczną wózka jest zastosowanie wewnętrznej ramy, co pozwoliło na zmniejszenie jego masy całkowitej oraz uzyskanie stosunkowo niedużej szerokości. Komfort podróżowania został zapewniony poprzez dwustopniowe usprężynowanie. Ogólny widok wózka został zaprezentowany na rys. $4 \mathrm{w}$ dwóch wariantach: $\mathrm{z}$ oraz bez stelaża podwieszenia. Stelaż ten służy mocowaniu pudła pojazdu, a więc stanowiąc jego integralną część, przesuwa się razem $\mathrm{z}$ nim względem wózka. $Z$ tego powodu jest on również miejscem mocowania czopa skrętu oraz niektórych thumików. Wybrane dane techniczne wózka zostały zestawione w tabeli 2 [4].

Tabela 2 Wybrane dane techniczne wózka

\begin{tabular}{|l|c|c|}
\hline Cecha & Jednostka & Wartość \\
\hline Prześwit toru & $\mathrm{mm}$ & 1435 \\
\hline Długość & $\mathrm{mm}$ & 2926 \\
\hline Szerokość & $\mathrm{mm}$ & 1789 \\
\hline Wysokość & $\mathrm{mm}$ & 1151 \\
\hline Średnica toczna koła nowego & $\mathrm{mm}$ & 750 \\
\hline Średnica toczna koła zużytego & $\mathrm{mm}$ & 700 \\
\hline Nacisk osi na tor & $\mathrm{t}$ & 11,97 \\
\hline Całkowita masa wózka & $\mathrm{kg}$ & 5475 \\
\hline Masa ramy wózka & $\mathrm{kg}$ & 604 \\
\hline Masa nieusprężynowana & $\mathrm{kg}$ & 1108 \\
\hline Masa usprężynowana I stopnia & $\mathrm{kg}$ & 4367 \\
\hline
\end{tabular}




\begin{tabular}{|l|c|c|}
\hline Total mass of the bogie & $\mathrm{kg}$ & 5475 \\
\hline Bogie frame mass & $\mathrm{kg}$ & 604 \\
\hline Unsprung bogie mass & $\mathrm{kg}$ & 1108 \\
\hline $\begin{array}{l}\text { Suspended bogie mass by the } \\
\text { primary suspension }\end{array}$ & $\mathrm{kg}$ & 4367 \\
\hline $\begin{array}{l}\text { Suspended bogie mass by the } \\
\text { secondary suspension }\end{array}$ & $\mathrm{kg}$ & 829 \\
\hline Bogie wheelbase & $\mathrm{mm}$ & 1600 \\
\hline $\begin{array}{l}\text { Distance of springs sets of primary } \\
\text { suspension }\end{array}$ & $\mathrm{mm}$ & 1068 \\
\hline $\begin{array}{l}\text { Distance of spring sets of secondary } \\
\text { suspension }\end{array}$ & $\mathrm{mm}$ & 1630 \\
\hline Distance of brake discs & 658 \\
\hline $\begin{array}{l}\text { Distance between dampers of } \\
\text { hunting motion }\end{array}$ & $\mathrm{mm}$ & \pm 60 \\
\hline Lateral movement of the car body &
\end{tabular}

\begin{tabular}{|l|c|c|}
\hline Masa usprężynowana II stopnia & $\mathrm{kg}$ & 829 \\
\hline Baza wózka & $\mathrm{mm}$ & 1600 \\
\hline Rozstaw sprężyn I st. & $\mathrm{mm}$ & 993 \\
\hline Rozstaw sprężyn II st. & $\mathrm{mm}$ & 1068 \\
\hline Rozstaw tarcz hamulcowych & $\mathrm{mm}$ & 1630 \\
\hline Rozstaw tłumików wężykowania & $\mathrm{mm}$ & 658 \\
\hline Przem. poprzeczne nadwozia & $\mathrm{mm}$ & \pm 60 \\
\hline
\end{tabular}

\subsection{Wheelset and axlebox}

Trailing wheelset (Fig. 5) consist of an axle with wheels pressed into it. In this case resilient wheels were used in order to reduce sound emission and vibrations. The axleboxes (Fig. 6), which are support points for the bogie frame, are placed between both wheels that is typical for an internal frame. As it was mentioned, this solution enables weight and bogie width reduction and minimalization of bending moments value which act on the axle. Therefore, axle diameter can be smaller that means there is less unsprung mass which combined with aforementioned advantages results in lower operating costs. Unfortunately this solution severely limits access to the bearings which have to be mounted on the axle before the wheels.

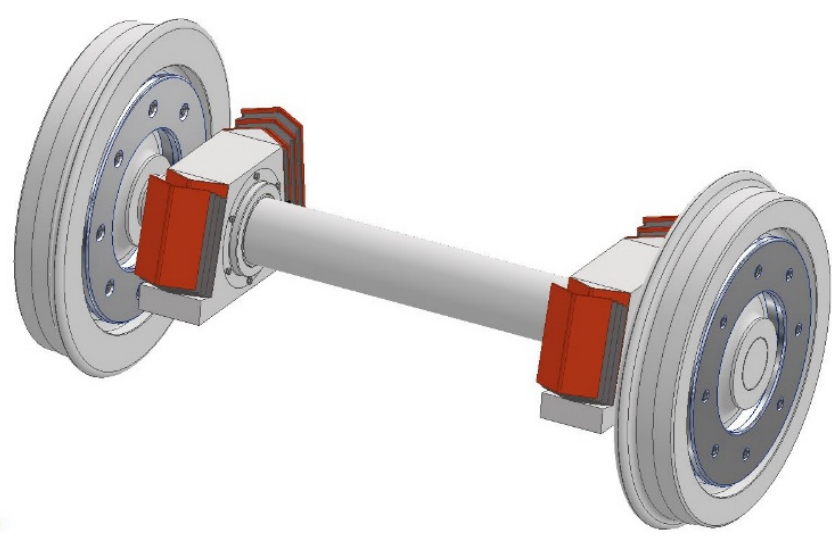

Fig. 5. Trailing wheelset with axleboxes and chevron springs [4] Rys. 5. Omaźnicowany, toczny zestaw kołowy [4]

Fig. 6 shows a cross-section view of the axlebox that contains compact tapered roller bearing unit CTBU 130x220 produced by SKF. This unit consists of two inner rings, a single outer ring and two rows of conical rollers guided inside polymeric cage. It comes as a single unit prepared for assembly. The bearing is sealed in a factory which assures high quality lubrication of rollers and no need to use additional seals in the axlebox body. Moreover, it is equipped with Axletronic system by SKF [7] where a single sensor integrated with a seal allows measurement of: rotational speed, temperature and vibration frequency. The first
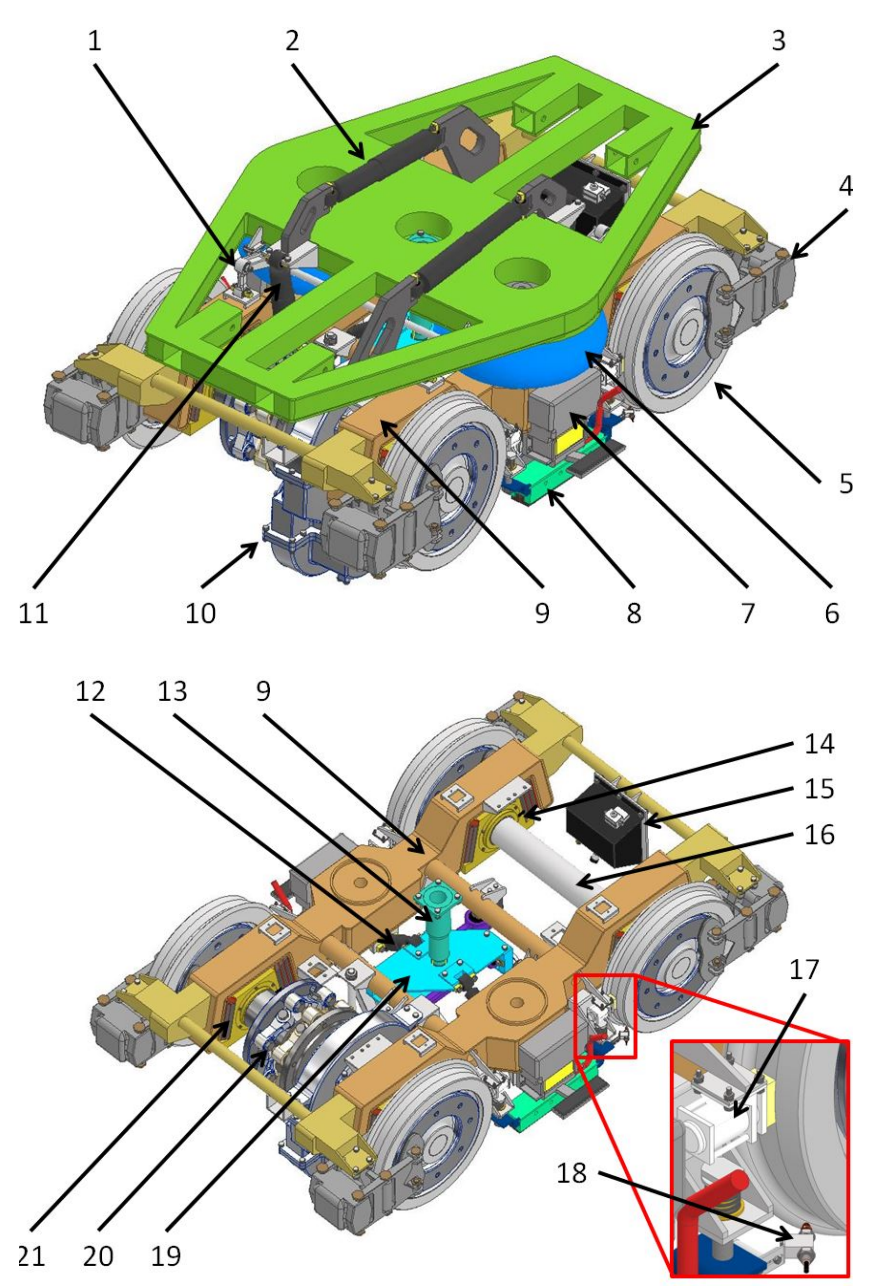

Fig. 4. Bogie components [4]: 1. Anti-roll bar; 2. Damper of hunting motion; 3. Suspension frame; 4. Disc brake unit; 5 . Wheelset; 6. Air spring; 7. Current collector; 8. Magnetic track brake; 9. Bogie frame; 10. Mechanical gear; 11. Vertical damper; 12. Horizontal damper; 13. Centre pivot; 14. Axlebox; 15. Grease reservoir; 16. Axle of the wheelset; 17 . Wheel tread cleaning unit; 18. Lubrication nozzle; 19. Watts linkage; 20. Coupling; 21. Chevron spring

Rys. 4. Budowa wózka [4]: 1. Stabilizator przechyłu poprzecznego nadwozia; 2. Tłumik wężykowania; 3. Stelaż podwieszenia; 4. Zacisk hamulca tarczowego; 5. Zestaw kołowy; 6. Sprężyna pneumatyczna; 7. Odbierak prądu; 8. Elektromagnetyczny hamulec szynowy; 9. Rama wózka; 10. Przekładnia mechaniczna; 11. Tłumik pionowy; 12. Tłumik poziomy; 13. Czop skrętu; 14. Maźnica; 15. Zbiornik smaru; 16. Oś zestawu kołowego; 17. Blok czyszczący; 18. Dysza smarująca; 19. Układ lemniskatowy; 20. Sprzęgło; 21. Sprężyna metalowo-gumowa typu klinowego

\subsection{Zestaw kołowy i maźnice}

Toczny zestaw kołowy (rys. 5) składa się z osi wraz z wtłoczonymi na nią kołami. W tym wypadku zastosowano koła z elementami metalowo-gumowymi w celu ograniczenia emisji dźwięku i drgań do środowiska. Widoczne na rys. 6 obudowy łożyskowe, będące punktami podparcia ramy wózka, zostały umiejscowione 
parameter is used by an anti-slip system and two others are used to assess the condition of the bearing. Bearing location on the wheelset's axle was defined by:

- front (3) and back (6) covers bolted into the axlebox body;

- $\quad$ stopper ring (7) set on the axle;

- locating ring (2) bolted to the axle which was necessary to ensure proper mounting of the bearing.

The powered wheelset construction is analogous with the difference that on the part of the axle between the axleboxes there is additionally a clutch hub.

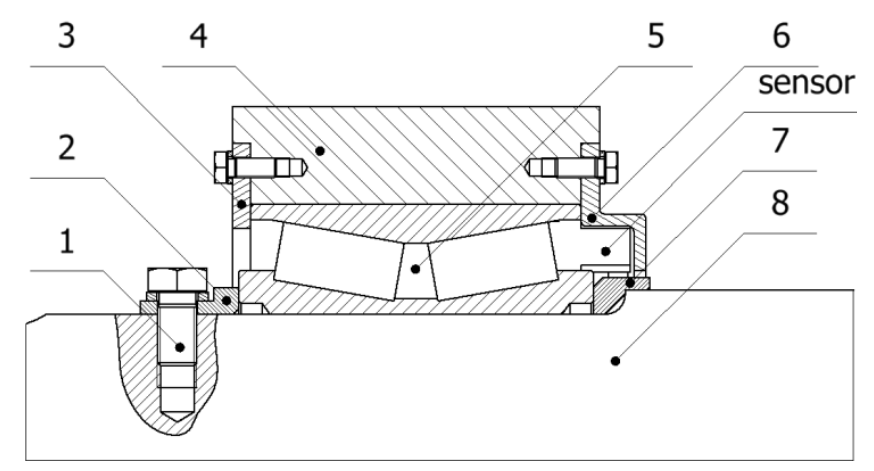

Fig. 6. Axlebox build [4]: 1. Fixing bolts; 2. Locating ring; 3. Front cover; 4 . Axlebox body; 5 . Rolling bearing-CTBU; 6 . Back cover; 7. Stopper ring; 8. Wheelset axle.

Rys. 6. Zabudowa łożyska zestawu kołowego [4]: 1. Śruba mocująca; 2. Pierścień ustalający; 3. Pokrywa przednia; 4. Korpus maźnicy; 5. Łożysko toczne-CTBU; 6. Pokrywa tylna; 7. Pierścień oporowy; 8. Oś zestawu kołowego.

\subsection{Wheelsets guidance}

The wheelsets are guided in a bogie frame by metalrubber, chevron springs (Fig. 5) that are primary suspension. This solution is characterised by simplicity because there are no additional parts as: swing arms (guidance with one-sided swing arm) or columns (column guidance) [8]. Moreover this type of springs have an internal damping loop which eliminates the need to use hydraulic vibration dampers in the primary suspension. Additionally they enable differentiating the stiffness in all three directions: longitudinal, lateral and vertical. A correct selection allows a quasi-radial adjustment of wheelsets in a track curve which means a lower wheel-rail attacking angle that results in a reduction of: motion resistance, lateral guidance force and wear of cooperating elements. Unfortunately, choosing an elastic guiding of the wheelsets lowers critical velocity of the vehicle which is also more prone to detrimental movements of all kinds [9]. Obviously, in a public transport vehicle that has a relatively low maximal speed aforementioned drawbacks aren't so important. There is also one additional issue connected with this kind of wheelset guidance - possibility of frame fatigue cracking near points where frame is supported on chevron springs, what took place in PESA 37AN bogies [10]. To prevent aforementioned troubles in the bogie construction, there could be additionally used pomiędzy obydwoma kołami zestawu, co jest charakterystyczne dla ramy wewnętrznej. Jak już wspomniano rozwiązanie takie pozwala na redukcję masy, zmniejszenie szerokości wózka oraz wartości momentów gnących oddziaływujących na oś zestawu kołowego. Umożliwia to zmniejszenie jej średnicy, a więc również masy nieusprężynowanej pojazdu, co razem z wcześniej wymienionymi zaletami, przekłada się na niższe koszty eksploatacyjne. Niestety rozwiazzanie takie znacznie pogarsza dostęp do węzłów łożyskowych, które należy osadzić na osi jeszcze przed montażem kół.

Rys. 6 przedstawia przekrój przez korpus maźnicy, w którym został zabudowany kompaktowy zespół łożysk stożkowych CTBU 130x220 firmy SKF. Zespół ten składa się z dwóch bieżni wewnętrznych, pojedynczej bieżni zewnętrznej oraz dwóch rzędów stożkowych elementów tocznych prowadzonych wewnątrz polimerowego koszyka, całość stanowi jeden element gotowy do montażu. Łożysko to zostało fabrycznie uszczelnione, co zapewnia wysoką jakość smarowania elementów tocznych oraz brak konieczności zabudowy dodatkowych uszczelnień w korpusie maźnicy. Ponadto zostało ono wyposażone w system Axletronic firmy SKF [7], w którym pojedynczy czujnik zintegrowany z uszczelnieniem umożliwia pomiar: prędkości obrotowej, temperatury oraz częstotliwości drgań. Pierwszy z parametrów jest wykorzystywany przez system antypoślizgowy, a dwa pozostałe stanowią podstawę do określenia aktualnego stanu łożyska.

Położenie łożyska na osi zestawu kołowego zostało ustalone za pomocą:

- $\quad$ pokrywy przedniej (3) i tylnej (6), dokręcanych do korpusu maźnicy;

- $\quad$ pierścienia oporowego (7), osadzonego na osi;

- pierścienia przesuwnego (2), dokręconego do osi, co umożliwia montaż łożyska.

Budowa napędnego zestawu kołowego jest analogiczna do wyżej opisanej z tą różnica, że na osi pomiędzy maźnicami dodatkowo osadzono piastę sprzęgła układu napędowego.

\subsection{Prowadzenie zestawów kołowych}

Zestawy kołowe prowadzone są w ramie wózka przy pomocy sprężyn metalowo-gumowych typu klinowego (rys. 5), pełniących jednocześnie rolę usprężynowania I stopnia. Rozwiązanie takie charakteryzuje się dużą prostotą, ze względu na brak występowania dodatkowych elementów takich jak: wahacze (prowadzenie jednostronnym wahaczem) czy kolumny (prowadzenie kolumnowe) [8]. Ponadto sprężyny tego typu charakteryzują się pętlą wewnętrznego tłumienia, co eliminuje konieczność stosowania hydraulicznych thumików drgań w I stopniu usprężynowania. Dodatkowo pozwalają one na uzyskanie różnych wartości sztywności we wszystkich trzech kierunkach: wzdłużnym, poprzecznym i pionowym. Odpowiedni ich dobór pozwala na 
elements fastened to the frame under the axlebox. Nevertheless such decision to slightly change bogie frame design could be justified only by fatigue calculations, which wasn't included in authors' project.

\subsection{Frame}

The vehicle uses a three-section, closed space frame, visible in Fig. 7 that consists of:

- two closed box-shaped side-sills (10 mm thick metal sheet made of S355 steel);

- two central cross-bar pipes (external diameter $100 \mathrm{~mm}$, internal $-70 \mathrm{~mm}$ );

- two pipes headstocks (external diameter $-60 \mathrm{~mm}$, internal - $30 \mathrm{~mm}$ ).

The whole frame is a welded structure, which should be subjected to vibratory relaxation or a stabilizing load in order to avoid welding stresses and to maintain appropriate dimensional tolerance.

The appropriate shape of the side-sills enables a stable support of the frame on chevron springs and provides a place for fixing secondary springs. In addition, the frame provides a number of mounting points for individual components and systems of the bogie.

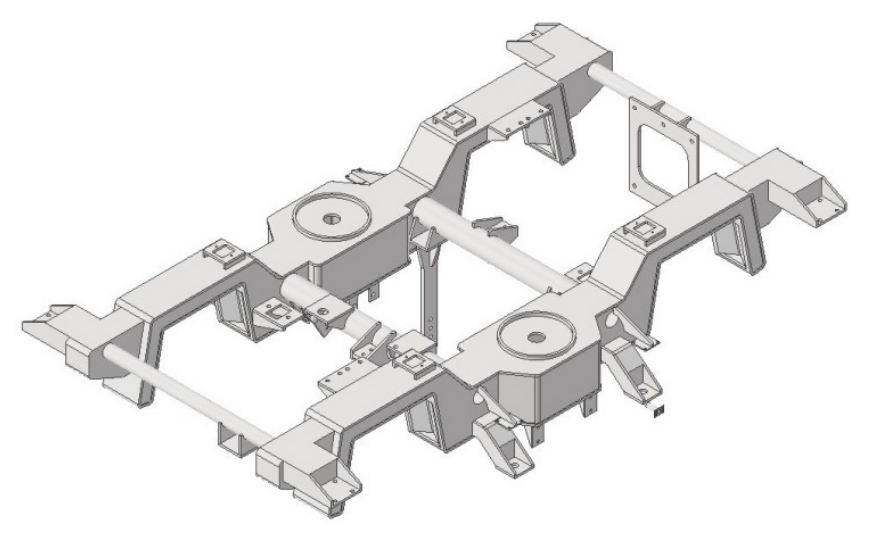

Fig. 7. Bogie frame [4]

Rys. 7. Rama wózka [4]

\subsection{Propulsion system}

The bogie is equipped with a single electric, asynchronous, inductive, squirrel-cage traction motor made by VEM marked DKLBZ 0910-04 that selected technical date are summarized in Table 3 . The motor is controlled by a traction inverter by changing the frequency of the supply current, which allows for practically any shaping of the vehicle's traction characteristics. The current is supplied by the current rail (third rail) and then a bottom-running-system current collector device cooperating with it. The tracks close the electrical circuit. Driving torque is transferred from the motor shaft to the gearbox input shaft via the Centaflex A flexible coupling. This coupling dampens torsional vibrations, reduces shock loads and compensates for significant axial, radial and angular displacements [11]. quasi-radialne ustawienie się zastawów kołowych w łuku torowym, a więc zmniejszenie kąta nabiegania koła na szynę, co skutkuje zmniejszeniem: oporów ruchu, poprzecznej siły prowadzącej oraz zużycia współpracujących elementów. Niestety przy doborze elastycznego prowadzenia zestawów kołowych następuje spadek wartości prędkości krytycznej pojazdu, który ponadto staje się bardziej podatny na wszelkiego rodzaju ruchy szkodliwe [9]. Oczywiście, w pojeździe komunikacji miejskiej o stosunkowo niskiej prędkości maksymalnej, powyższe wady nie stanowią większej przeszkody.

Warto również nadmienić, że w wózku z tym typem prowadzenia zestawów kołowych, może dochodzić do pęknięć zmęczeniowych w okolicach oparcia ramy na sprężynach klinowych, czego przykładem moga być wózki 37AN produkcji PESY [10]. W celu niedopuszczenia do tego typu uszkodzeń, w zaprezentowanej konstrukcji można by zastosować dodatkowy element (np. w postaci płaskownika) mocowany do ramy bezpośrednio poniżej obudowy łożyska. Jednak decyzję tego typu można umotywować jedynie obliczeniami zmęczeniowymi, które znacznie wykraczają poza ramy niniejszego opracowania.

\subsection{Rama}

W pojeździe zastosowano trójobwodową, zamkniętą ramę przestrzenną, widoczną na rys. 7 , która składa się $\mathrm{z}:$

- dwóch ostojnic o zamkniętej konstrukcji skrzynkowej (arkusze blachy o grubości $10 \mathrm{~mm}$, wykonane ze stali S355);

- dwóch rurowych poprzecznic (średnica zewnętrzna $-100 \mathrm{~mm}$, wewnętrzna $-70 \mathrm{~mm}$ );

- dwóch rurowych czołownic (średnica zewnętrzna $-60 \mathrm{~mm}$, wewnętrzna $-30 \mathrm{~mm}$ ).

Całość ramy stanowi konstrukcję spawaną, która dla uniknięcia naprężeń spawalniczych i zachowania odpowiedniej tolerancji wymiarowej powinna zostać poddana odprężeniu wibracyjnemu lub obciążeniu stabilizującemu. Odpowiedni kształt ostojnic umożliwia stabilne oparcie ramy na sprężynach klinowych oraz zapewnia miejsce mocowania elementów usprężynowania II stopnia. Ponadto $\mathrm{w}$ ramie przewidziano szereg punktów montażowych dla poszczególnych podzespołów i układów wózka.

Wózek wyposażony jest w pojedynczy elektryczny, asynchroniczny, indukcyjny, klatkowy silnik trakcyjny firmy VEM o oznaczeniu DKLBZ 0910-04, którego wybrane dane techniczne zostały zestawione w tabeli 3. Sterowanie silnikiem odbywa się za pomocą falownika trakcyjnego, poprzez zmianę częstotliwości prądu zasilającego, co pozwala na praktycznie dowolne kształtowanie charakterystyki trakcyjnej pojazdu. Zasilanie składu odbywa się poprzez szynę prądową (tzw. trzecia szyna) i współpracujący z nią odbierak prądu o ślizgu dolnym. Sieć powrotną stanowią tory. Moment 
Table 3. Technical specification of the traction motor VEM DKLBZ 0910-04 [4]

\begin{tabular}{|l|c|c|}
\hline Feature & Unit & Value \\
\hline Motor mass & $\mathrm{kg}$ & 627 \\
\hline Nominal power & $\mathrm{kW}$ & 280 \\
\hline Nominal rotational speed & $\mathrm{obr} / \mathrm{min}$ & 1624 \\
\hline Maximal rotational speed & $\mathrm{obr} / \mathrm{min}$ & 4279 \\
\hline Nominal torque & $\mathrm{Nm}$ & 1646 \\
\hline Nominal frequency & $\mathrm{Hz}$ & 55 \\
\hline Nominal efficiency & - & 0,943 \\
\hline
\end{tabular}

The bogie uses a two-stage gearbox with a first stage with bevel gears (gear ratio: 1,80 ) and a second stage consisting of helical gears (gear ratio 4,40). A helical gear with a larger pitch diameter was mounted on a sleeve acting as the output shaft from the gearbox. This sleeve is mounted in the gear housing, and through its inner hole passes the axle of the wheelset, to which the torque is transmitted via the Centalink coupling. This coupling consists of two flanges (one mounted on the axle and second one on the gearbox output shaft), connected with each other by an inter-clutch shaft made of carbon fibre reinforced polymer. The torque between individual flanges and the shaft is transferred through six links with flexible bushes [11]. This type of construction provides a constant velocity transmission of the clutch and a compensation of axial, radial and angular displacements between the axle and output shaft of the gearbox.

The above-described design of the propulsion system (Fig. 8) means that the wheelset's axle is not additionally loaded with the weight of the gearbox or motor but only with the driving torque (twisting moment). It also prevents the vibrations between the gearbox and the motor. Moreover, by fixing both elements in the bogie frame (Fig. 9), its unsprung mass is reduced.

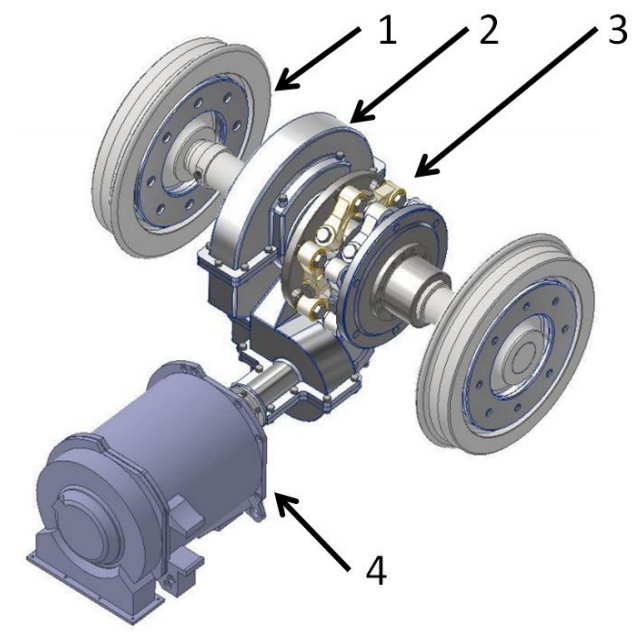

Fig. 8. Components of the propulsion system [4]: 1. Wheelset; 2. Gearbox; 3. Centaflex A coupling; 4. Motor.

Rys. 8. Elementy składowe układu napędowego [4]: 1. Zestaw kołowy; 2. Przekładnia mechaniczna; 3. Sprzęgło Centaflex A; 4. Silnik trakcyjny. napędowy przenoszony jest $\mathrm{z}$ wału silnika na wał wejściowy przekładni za pośrednictwem sprzęgła podatnego Centaflex A. Sprzęgło to tłumi drgania skrętne, łagodzi obciążenia udarowe i kompensuje znaczne przesunięcia osiowe, promieniowe i kątowe [11].

Tabela 3. Dane techniczne silnika VEM DKLBZ 0910-04 [4]

\begin{tabular}{|l|c|c|}
\hline Cecha & Jednostka & Wartość \\
\hline Całkowita masa silnika & $\mathrm{kg}$ & 627 \\
\hline Moc znamionowa & $\mathrm{kW}$ & 280 \\
\hline Prędkość obrotowa znamionowa & $\mathrm{obr} / \mathrm{min}$ & 1624 \\
\hline Prędkość obrotowa maksymalna & $\mathrm{obr} / \mathrm{min}$ & 4279 \\
\hline Moment znamionowy & $\mathrm{Nm}$ & 1646 \\
\hline Częstotliwość znamionowa & $\mathrm{Hz}$ & 55 \\
\hline Sprawność znamionowa & - & 0,943 \\
\hline
\end{tabular}

\subsection{Układ napędowy}

W wózku zastosowano dwustopniową przekładnię zębatą, z pierwszym stopniem stożkowym (przełożenie 1,80 ) i drugim walcowym (przełożenie 4,40). Walcowe koło zębate o większej średnicy podziałowej zostało osadzone na tulei pełniącej rolę wału wyjściowego z przekładni. Tuleja ta ułożyskowana jest $\mathrm{w}$ korpusie przekładni, a przez jej wewnętrzny otwór przechodzi oś zestawu kołowego, na który moment obrotowy przenoszony jest za pośrednictwem sprzęgła Centalink. Sprzęgło to składa się z dwóch tarcz (jednej osadzonej na osi, a drugiej na wale wyjściowym przekładni), połączonych ze sobą wałem międzysprzęgłowym wykonanym z kompozytu o osnowie zbrojonej włóknem węglowym. Moment pomiędzy poszczególnymi tarczami, a wałem międzysprzęgłowym przenoszony jest za pośrednictwem sześciu cięgien, których łby są wyposażone w elementy gumowe [11]. Taka budowa zapewnia równobieżną pracę sprzęgła oraz kompensację przemieszczeń osiowych, promieniowych i kątowych występujących pomiędzy osią, a wałem przekładni.

Opisana powyżej konstrukcja układu napędowego (rys. 8) sprawia, że oś zestawu kołowego nie jest dodatkowo obciążona masą przekładni czy silnika, a jedynie momentem napędowym (moment skręcający). Nie dopuszcza ona również do przenoszenia drgań pomiędzy przekładnią i silnikiem. Ponadto, mocowanie obu elementów w ramie wózka (rys. 9) ogranicza jego masę nieusprężynowaną.

Powodem wzdłużnego umiejscowienia silnika była ograniczona przestrzeń pomiędzy ostojnicami ramy, wynosząca jedynie $805 \mathrm{~mm}$ oraz konieczność wpłynięcia na zmianę położenia środka ciężkości, tak aby zapewnić równomierny rozkład obciążenia pomiędzy obie osie. Z uwagi na krótką bazę wózka, silnik usytuowano w taki sposób, że jego oś symetrii znalazła się na płaszczyźnie łączącej główki obu szyn. Rozwiązanie takie jest możliwe dzięki jednostronnie otwartemu profilowi belki jezdnej (rys. 3) oraz odpowiedniej konstrukcji przekładni mechanicznej. W mocowaniach zarówno przekładni jak i silnika, wykorzystano elementy podatne, w celu wibroizolacji wymienionych podzespołów. 
The reason of longitudinal placement of the motor was limited space between the bogie's side-sills (only 805 $\mathrm{mm}$ ) and the necessity to change the position of the centre of gravity so as to ensure an even distribution of load between both axles. Due to short base of the bogie, the motor was located in such a way that its axis of symmetry was on the plane connecting the heads of both rails. This solution is possible thanks to the onesided open profile of the guideway beam (Fig. 3) and the appropriate design of the mechanical gearbox.

In the mountings of both the gearbox and the motor, flexible elements were used in order to vibro-isolate these components

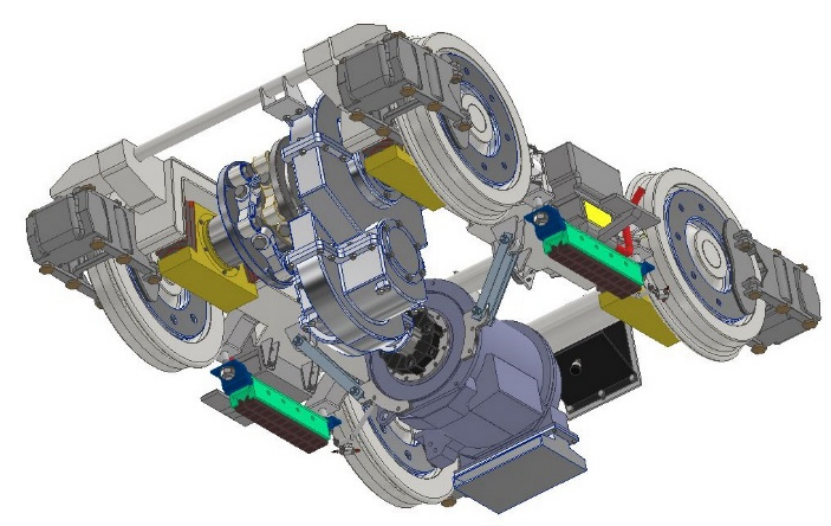

Fig. 9. Assembly of propulsion system in the bogie [4] Rys. 9. Widok układu napędowego w wózku [4]

\subsection{Secondary suspension}

Secondary suspension is provided by two air springs of the company Trelleborg - 45/1107 [12] (Fig. 10), with a load capacity of $114 \mathrm{kN}$ each. The horizontal deformation of the spring is $\pm 120 \mathrm{~mm}$, so it is sufficient for bolsterless bogie. The spring is embedded in the frame of the bogie by placing the fixing pin in a tubular element welded inside the side-sill. The suspension frame is supported on an air spring plate that works with a round clamp welded to its surface.

According to the diagram in Fig. 11, in addition to the air springs in the pneumatic system of the secondary suspension, the following can be distinguished:

- $\quad$ auxiliary reservoir (3), build inside the suspension frame, provides additional volume allowing for reduction of spring stiffness. Moreover, the insertion of the orifice between the two elements ensures a damping effect;

- $\quad$ shuttle valve (2) supplies a pneumatic signal to the brake system with a pressure equal to that of the more loaded spring, which allows the brake force to be selected as a function of the vehicle load;

- two check valves $(4.1,4.2)$ allow pressure equalization between the springs. For example, when one of the springs is punctured, one of the pair of valves will allow the working medium to flow towards the damaged spring, thanks to which the body will be supported by the emergency springs on both its sides;

\subsection{Usprężynowanie II stopnia}

Usprężynowanie II stopnia realizowane jest poprzez dwie sprężyny pneumatyczne firmy Trelleborg 45/1007 [12] (rys. 10), o nośności 114 kN każda. Odkształcalność poprzeczna sprężyny wynosi $\pm 120 \mathrm{~mm}$, a więc jest wystarczająca do eliminacji belki skrętnej. Każda ze sprężyn osadzona jest $\mathrm{w}$ ramie wózka poprzez umiejscowienie sworznia mocującego w elemencie rurowym, wspawanym wewnątrz ostojnicy. Z kolei stelaż podwieszenia oparty jest na płycie mocującej, która współpracuje z okragłą obejmą dospawaną do jego powierzchni.

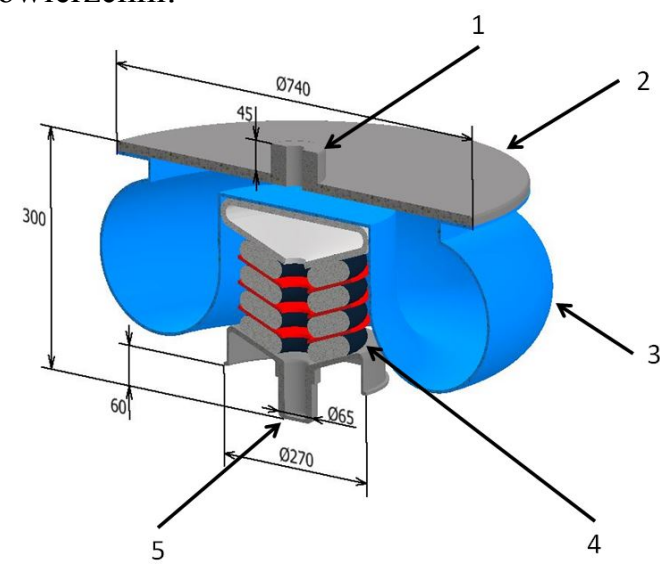

Fig. 10. Air spring model [4]: 1. Air supply; 2. Air spring plate; 3. Air bag; 4. Emergency spring; 5. Fixing pin.

Rys. 10. Model sprężyny pneumatycznej [4]: 1. Przyłącze pneumatyczne; 2. Płyta mocująca; 3. Miech; 4. Sprężyna awaryjna; 5. Sworzeń mocujący.

Zgodnie ze schematem z rys. 11, oprócz sprężyn pneumatycznych w układzie pneumatycznym usprężynowania II stopnia można wyróżnić:

- zbiornik pomocniczy (3), zabudowany we wnętrzu stelaża podwieszenia, stanowi dodatkową objętość pozwalającą na zmniejszenie sztywności sprężyny. Ponadto wprowadzenie pomiędzy oba elementy zwężki zapewnia uzyskanie efektu thumienia;

- zawór alternatywy (2) dostarcza sygnał pneumatyczny do układu hamulcowego, o ciśnieniu równym ciśnieniu panującemu $\mathrm{w}$ bardziej obciążonej sprężynie, co pozwala na dostosowanie siły hamowania do obciążenia pojazdu;

- dwa zawór zwrotne $(4.1,4.2)$ umożliwiają wyrównanie ciśnień pomiędzy sprężynami w sytuacjach awaryjnych. Przykładowo w momencie przebicia jednej ze sprężyn, jeden z pary zaworów umożliwi przepływ medium roboczego w kierunku uszkodzonej sprężyny, dzięki czemu nadwozie zostanie oparte na sprężynach awaryjnych po obu swoich stronach;

- zawór ważący (5) reguluje natężenie przepływu medium roboczego do danej sprężyny. Jest on zamocowany $\mathrm{w}$ nadwoziu i połączony za pomocą dźwigni o nastawnej długości, $\mathrm{z}$ ramą. Wraz ze wzrostem obciążenia pojazdu zmniejszeniu ulega odległość pomiędzy stelażem i ostojnica, a więc 
- levelling valve (5) regulates the flow rate of the working medium to the given spring. It is fixed to the car body and connected to the frame by an adjustable length lever. As the load on the vehicle increases, the distance between the suspension frame and the side-sill decreases, and the valve allows airflow to the spring. When the load is reduced, the valve connects the spring volume with the atmosphere, leading to a drop of a pressure in the spring. This way the levelling valve makes it possible to maintain a constant distance between the body and the bogie, and therefore the platform.

In addition, the system uses a reduction valve that limits the operating pressure of the springs, and a filter that cleans the air of contaminants. The working medium is taken from the vehicle's main reservoir pipe, where it is subjected to appropriate preparation in advance.

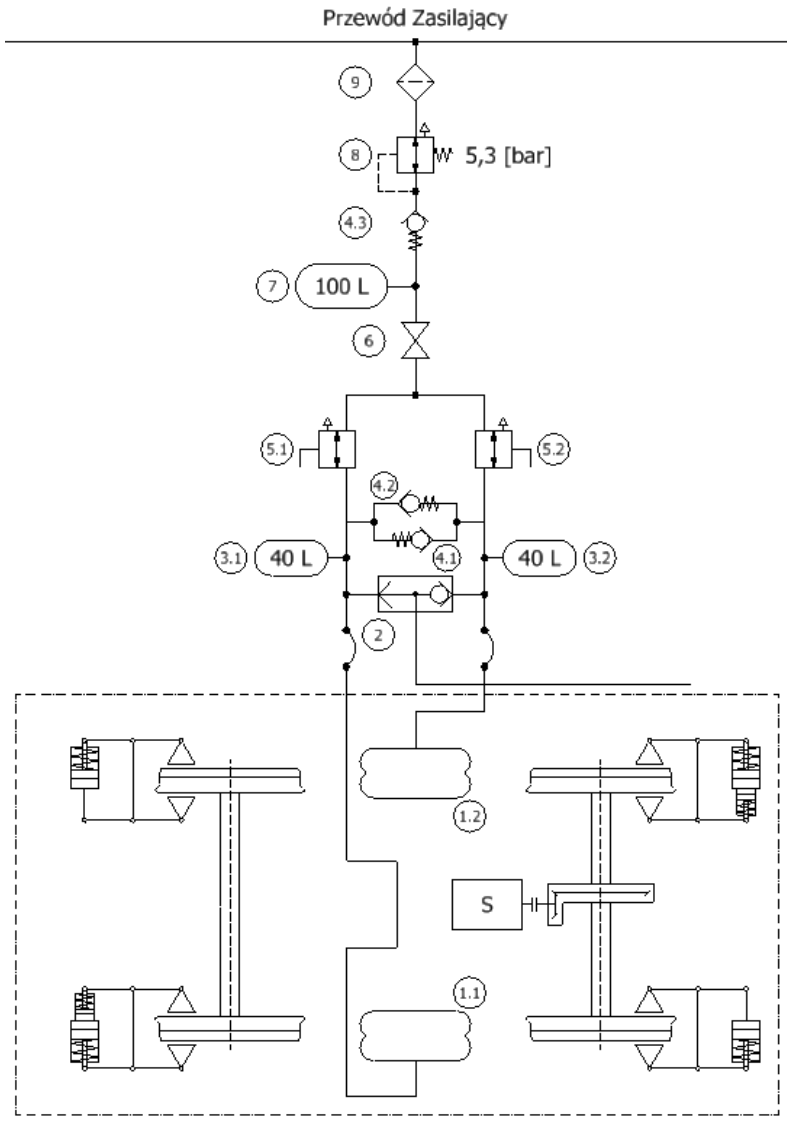

Fig. 11. Pneumatic system of secondary suspension [4]: 1. Air spring; 2 . Shuttle valve; 3 . Auxiliary reservoir; 4 . Check valve; 5 . Levelling valve; 6 . Shut-off valve; 7. Main reservoir; 8 . Pressurereducing valve; 9 . Filter.

Rys. 11. Układ pneumatyczny usprężynowania II stopnia [4]: 1. Sprężyna pneumatyczna; 2. Zawór alternatywy; 3. Zbiornik pomocniczy; 4. Zawór zwrotny; 5. Zawór ważący (poziomujący); 6. Zawór odcinający; 7. Zbiornik główny; 8. Zawór redukcyjny; 9. Filtr.

In order to assure high travel comfort, the secondary suspension should have the lowest possible stiffness and should cooperate with vertical hydraulic dampers. In such a combination, the springs reduce the accelera-
- dochodzi do przesterowania zaworu, który umożliwia dopływ powietrza do sprężyny. W przypadku zmniejszenia obciążenia, zawór łączy objętość sprężyny z atmosfera, prowadząc do spadku panującego w niej ciśnienia. W ten sposób zawór ważący umożliwia utrzymanie stałej odległości pomiędzy nadwoziem i wózkiem, a więc i peronem.

Ponadto w układzie wykorzystano zawór redukcyjny, ograniczający ciśnienie pracy sprężyn, oraz filtr, oczyszczający powietrze z zanieczyszczeń. Medium robocze pobierane jest $\mathrm{z}$ przewodu zasilającego pojaz$\mathrm{du}$, gdzie wcześniej podlega odpowiedniemu przygotowaniu.

W celu zapewnienia ogólnie pojętego komfortu jazdy pasażerów usprężynowanie II stopnia powinno charakteryzować się możliwie niską sztywnością oraz powinno współpracować z pionowymi thumikami hydraulicznymi. W takim zestawieniu sprężyny odpowiadają za redukcję przyspieszeń nadwozia, a thumiki za wythumianie drgań o niskich częstotliwościach. Jednocześnie niska sztywność sprężyn może doprowadzić do nadmiernego przechyłu nadwozia, zwłaszcza w osi symetrii toru, co w skrajnych przypadkach prowadzi do utraty stateczności pojazdu. $Z$ tego względu w wózku zastosowano stabilizator przechyłu poprzecznego nadwozia (rys. 12), który zwiększa sztywność poprzeczną usprężynowania II stopnia. W wózku zabudowano dwa stabilizatory przechyłu poprzecznego nadwozia, zamocowane symetrycznie względem płaszczyzny pionowej przechodzącej przez obie sprężyny pneumatyczne. Każdy ze stabilizatorów składa się z drążka skrętnego i dospawanej do niego pary ramion. Drążek ten ułożyskowany na obu swoich końcach jest zamocowany w stelażu podwieszenia. Każde z ramion połączone jest $\mathrm{z}$ daną ostojnicą ramy przy pomocy cięgna, w którego łbach umieszczone sa podatne przeguby, pozwalające na swobodny obrót wózka względem nadwozia.

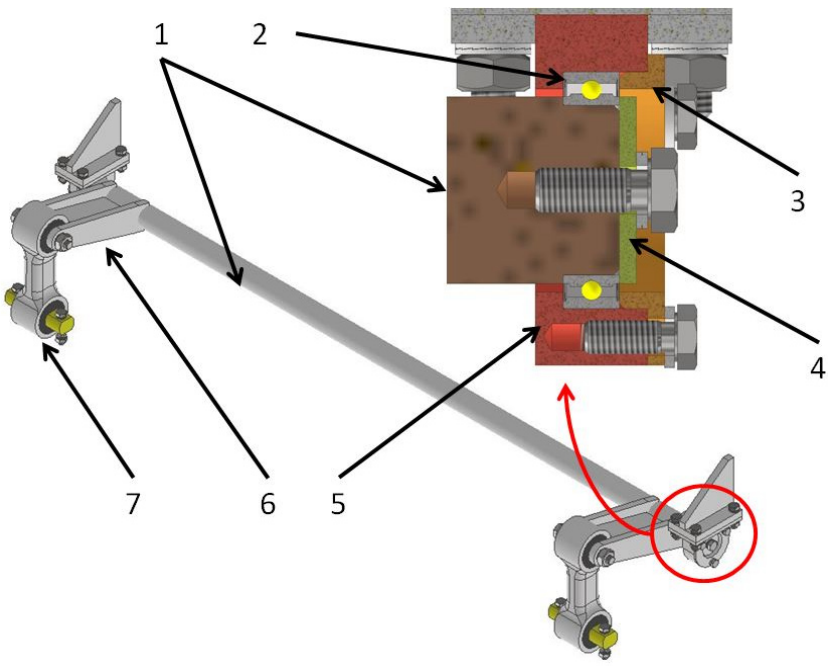

Fig. 12. Anti-roll bar [4]: 1. Torsion bar; 2. Rolling bearing; 3 . Cover; 4. Fixing element; 5. Body; 6. Torsion arm; 7. Link.

Rys. 12. Stabilizator przechyłu poprzecznego nadwozia [4]: 1. Drążek skrętny; 2. Łożysko toczne; 3. Pokrywa; 4. Krążek ustalający; 5. Korpus; 6. Ramie; 7. Cięgno. 
tion of the car body, and the dampers diminish vibrations at low frequencies. At the same time, the low stiffness of the springs may lead to excessive car body tilt, especially in the track symmetry axis, which in extreme cases leads to a loss of movement stability. For this reason, the bogie features an anti-roll bar (Fig. 12), which increases the lateral stiffness of the secondary suspension. In the bogie there are two anti-roll bars, placed symmetrically in relation to the vertical plane passing through both air springs. Each of them is composed of a torsion bar mounted at its both ends to which two arms are welded. Each of the arms is connected to a given side-sill by a link, in the heads of which there are flexible joints, that allow the bogie to rotate freely in relation to the car body. Both bearing housings are bolted to the suspension frame. Tilting the car body to one side causes the torsion bar arms to rotate in opposite directions, resulting in a torsional load on the bar. If it is characterized by sufficient torsional stiffness, it is an element limiting the movements of the arms in relation to each other, and thus also the movement of the car body.

\subsection{Tractive force transmission}

The tractive force is transferred between the bogie and the body by traction links, which, connecting the central crossbars of the frame with the yoke, are built in a lemniscate system (Fig. 13). Such a configuration allows for undisturbed lateral movement of the yoke, and thus the car body, in relation to the bogie, while maintaining appropriate longitudinal stiffness. In the yoke there is a centre pivot socket with a friction lining, generating a frictional moment counteracting detrimental rotational movements of the bogie resulting from the uneven track. This lining works with a centre pivot, rigidly fixed in the suspension frame. In addition to the yoke, instead of directly to the suspension frame, a pair of horizontal hydraulic dampers was attached. The susceptibility and vibration damping in the tractive force transmission is realized in the flexible heads of the links, the construction of which allows the entire system to move in relation to the bogie frame.

Presented solution allowed for the lowest possible position (in relation to the rail head) of the traction force transfer point and maintaining the weight of the bogie low. The height is limited by the position of the traction motor directly below the yoke. The use of tubular crossbars contributed to the reduction in weight, rather than a single cross-beam with a closed box structure. The maximum value of the lateral movement of the yoke was limited to $\pm 60 \mathrm{~mm}$ by a pair of bumpers mounted on the central crossbars of the frame (Fig. 14).

Bolted connections were used in the construction of the yoke, links mount and vibration dampers. These connections, as well as all the others in the bogie, were secured against spontaneous loosening (due to vibrations) by wedge washers.
Przechył nadwozia na jedną ze stron, powoduje obrót ramion drążka skrętnego w przeciwnych kierunkach, co skutkuje jego obciążeniem momentem skręcającym. Jeżeli charakteryzuje się on wystarczającą sztywnością skrętną, to stanowi element ograniczający ruchy ramion względem siebie, a więc również ruch nadwozia.

\subsection{Układ przenoszenia siły pociągowej}

Siła pociagowa przenoszona jest pomiędzy wózkiem, a nadwoziem za pomocą pary cięgien trakcyjnych, które łącząc poprzecznice centralne ramy z jarzmem zabudowane są w układzie lemniskatowym (rys. 13). Taka konfiguracja pozwala na niezakłócony przesuw poprzeczny jarzma, a więc i nadwozia względem wózka, przy jednoczesnym zachowaniu odpowiedniej sztywności wzdłużnej. W jarzmie umiejscowione jest gniazdo czopa skrętu wyłożone okładziną cierną, generującą moment tarcia przeciwdziałający szkodliwym ruchom obrotowym wózka, wynikającym z nierówności toru. Z okładziną tą współpracuje czop skrętu, sztywno umocowany w stelażu podwieszenia. Dodatkowo do jarzma, zamiast bezpośrednio do stelaża podwieszenia zamocowano parę hydraulicznych tłumików poziomych. Z kolei podatność i tłumienie drgań w układzie przenoszenia sił trakcyjnych jest realizowane w podatnych łbach cięgien, których konstrukcja pozwala jednocześnie na przemieszczenie poprzeczne całego układu względem ramy wózka. Rozwiązanie takie pozwoliło na możliwie niskie usytuowanie (względem główki szyny) punktu przenoszenia siły trakcyjnej oraz utrzymanie niskiej masy wózka. Dla wspomnianej wysokości ograniczenie stanowi położenie silnika trakcyjnego bezpośrednio poniżej jarzma. Z kolei do redukcji masy przyczyniło się zastosowanie poprzecznic rurowych, a nie pojedynczej poprzecznej belki centralnej o zamkniętej konstrukcji skrzynkowej. Maksymalna wartość przesuwu poprzecznego jarzma została ograniczona do $\pm 60 \mathrm{~mm}$ przez parę odbijaków, mocowanych na poprzecznicach centralnych ramy (rys. 14).

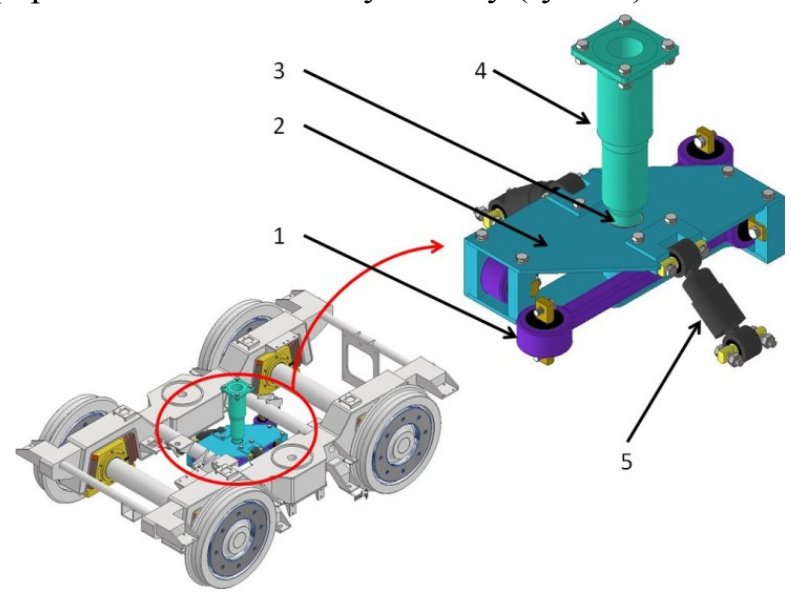

Fig. 13. Watts linkage build (also known as lemniscate system) [4]: 1. Traction rod; 2 . Yoke; 3 . Centre pivot socket; 4 . Centre Pivot; 5. Horizontal damper.

Rys. 13. Budowa układu lemniskatowego czopa skrętu [4]: 1. Cięgno trakcyjne; 2. Jarzmo; 3. Gniazdo czopa skrętu; 4. Czop skrętu; 5. Tłumik poziomy. 


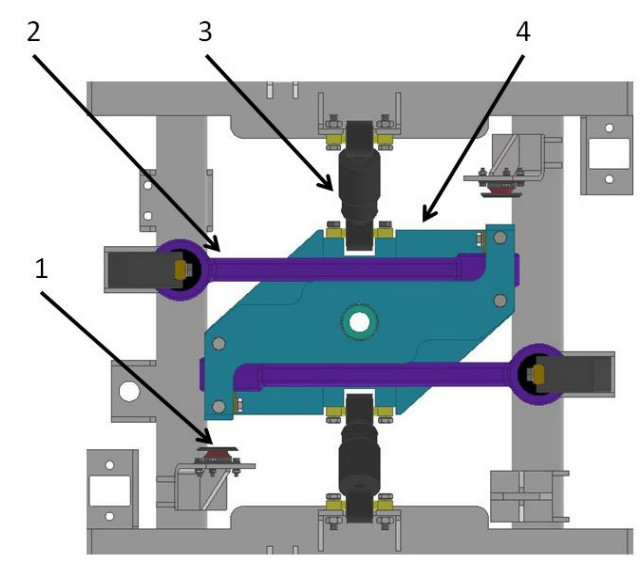

Fig. 14. Watts linkage - view from track side [4]: 1. Buffer; 2 . Traction rod; 3. Horizontal damper; 4. Yoke.

Rys. 14. Układ lemniskatowy - widok od strony toru [4]: 1. Odbijak; 2. Cięgno trakcyjne; 3 . Tłumik poziomy; 4. Jarzmo

\subsection{Braking system}

In the bogie, as well as in the whole vehicle, were used three types of brakes: electrodynamic, disc and magnetic track (also known as electromagnetic rail brake or simply rail brake). The highest possible braking power should be executed by the electrodynamic brake (socalled regenerative brake) as it is a frictionless brake enabling recuperation of electric energy. However, it only generates the braking force on powered wheelsets and its value tends to zero at low speeds. Therefore, this type of brake must cooperate with a friction brake (so-called blending). In the described bogie, it was decided to use a disc brake, which, unlike a tread brake, does not increase the roughness of the wheels treads (increase in sound emission), their thermal load or increased wear.

In the bogie there are four wheel-mounted brake units (Fig. 15) equipped with adjusters that regulate the distance between the brake lining and the brake disc. In addition, one of the callipers on each wheelset is integrated with the spring brake. The brake linings and their maximum pressure force have been selected in such a way that the generated braking force is greater than the adhesion forces, which can be implemented thanks to the use of an anti-skid system.

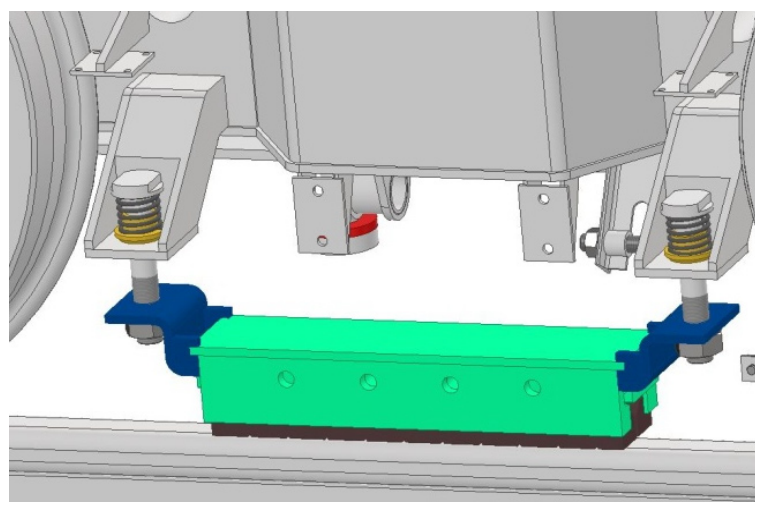

Fig. 16. Magnetic track brake [4]

Rys. 16. Elektromagnetyczny hamulec szynowy [4]
W konstrukcji jarzma, w mocowaniu cięgien czy tłumików drgań, wykorzystano połączenia śrubowe. Połączenia te jak i wszystkie inne w wózku, zostały zabezpieczone przed samoistnym luzowaniem się (na skutek drgań) za pomocą podkładek klinowych.

\subsection{Układ hamulcowy}

W wózku, jak i całym pojeździe, zastosowano trzy rodzaje hamulców: elektrodynamiczny, tarczowy oraz elektromagnetyczny szynowy. Możliwie duża moc hamowania powinna być realizowana przez hamulec elektrodynamiczny jako, że jest on hamulcem beztarciowym umożliwiającym rekuperację energii elektrycznej. Jednak generuje on siłę hamującą jedynie na zestawach napędnych, a jej wartość dąży do zera przy małych prędkościach. W związku z tym ten rodzaj hamulca musi współpracować $\mathrm{z}$ hamulcem ciernym (tzw. blending). W opisywanym wózku zdecydowano się na zastosowanie hamulca tarczowego, który w przeciwieństwie do hamulca klockowego nie powoduje wzrostu chropowatości powierzchni tocznych kół (wzrost emisji dźwięku), ich obciążenia termicznego czy wzmożonego zużycia.

W wózku zabudowano cztery zaciski hamulca tarczowego (rys. 15) wyposażone w nastawiacze, regulujące odległość okładziny ciernej od tarczy hamulcowej. Ponadto jeden z zacisków na każdym zestawie kołowym, zintegrowany jest $\mathrm{z}$ hamulcem sprężynowym. Okładziny cierne oraz maksymalna siła ich docisku zostały dobrane w taki sposób, aby wytwarzana siła hamująca była większa od sił przyczepności, co jest możliwe do wdrożenia dzięki zastosowaniu systemu antypoślizgowego.

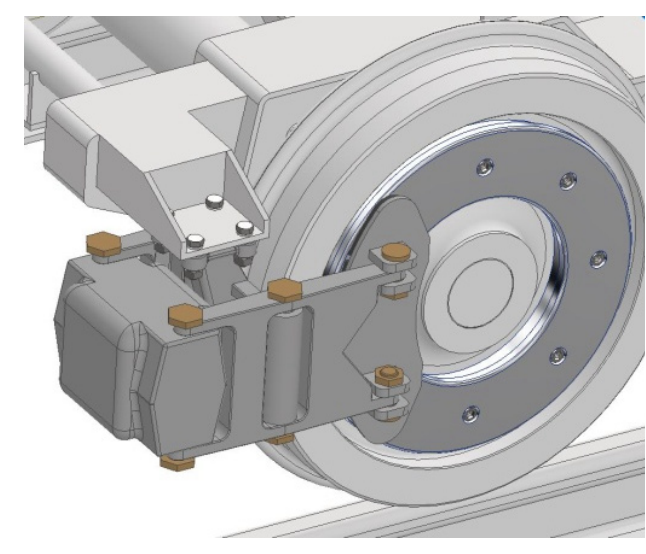

Fig. 15. Wheel-mounted disk brake unit [4] Rys. 15. Zacisk hamulca tarczowego [4]

W czasie hamowania nagłego wykorzystywany jest elektromagnetyczny hamulec szynowy, którego siła hamowania nie jest ograniczona siłami przyczepności na styku koło-szyna. Po obu stronach wózka pomiędzy zestawami kołowymi podatnie zamocowano dwie niezależne płozy hamulcowe (rys. 16). Każda z nich, o długości $500 \mathrm{~mm}$, zawieszona jest $\mathrm{w}$ odległości około $7 \mathrm{~mm}$ od powierzchni główki szyny, a siła docisku generowana przez elektromagnes osiaga $36 \mathrm{kN}$ [13]. 
During emergency braking, a magnetic track brake is used, which braking force is not limited by the adhesion forces at the wheel-rail contact. The bogie has two independent drag shoes elastically suspended between the wheelsets (Fig. 16), on both sides of the bogie. Each of them, $500 \mathrm{~mm}$ long, is suspended at a distance of about $7 \mathrm{~mm}$ from the surface of the rail head, and the attractive force generated by the electromagnet reaches $36 \mathrm{kN}$ [13].

\subsection{Lubrication of the wheel flanges and condition- ing of the wheel tread}

Lubrication of the wheel flanges in rail vehicle allows reduction of:

- motion resistance;

- the probability of derailment (increase in the permissible ratio of lateral to vertical force);

- $\quad$ sound emission;

- wear of wheels and rails.

All these advantages apply to movement in track curves when there is contact between the flange of the wheel and the rail head. The bogie uses the SKF EasyRail system [7] consisting of: a curve detection sensor, a grease reservoir and a lubricating nozzle. The air supplied from the vehicle's pneumatic system is mixed with lubricant and then sprayed on the wheel flange surface. Only the trailing wheelset is subject to direct lubrication (Fig. 17), and the grease remaining on the rail is automatically applied to the flanges of the powered wheelset (trailing wheelsets are always at the beginning of the rolling stock).

Reduced roughness of the wheel tread, resulting from the use of disc brakes (the lack of an element cleaning them from potential contamination e. g. brake shoe of a tread brake), results in a decrease in the coefficient of adhesion at the wheel-rail contact. In order to counteract this phenomenon, a cleaning unit has been applied to each wheel (Fig. 17), which is periodically pressed against the wheel tread. The brake system controller decides on the frequency and force of the contact pressure.

\section{SUMMARY}

This article described suspended rail vehicle bogie construction and applied technical solution. In comparison to Eugen Langen system, proposed bogie enables vehicle car body symmetrical suspension (that improves its stability during movement) also it increases safety and decreases wear of cooperating elements (wheel-rail) thanks to elastic wheelset guidance. On the other hand, comparison with SAFAGE system reveals less complicated construction of proposed bogie, through the use of steel wheels, which ensures vehicle guidance in a track (without any additional wheels). At the same time they are characterised by less wear and lower running resistance in contrast to rubber tires. Moreover presented construction fulfils all project assumptions:

\subsection{Smarowanie obrzeży kół oraz kondycjonowanie ich powierzchni tocznych}

Smarowanie obrzeży kół w pojeździe szynowym pozwala na zmniejszenie:

- oporów ruchu;

- prawdopodobieństwa wykolejenia (wzrost dopuszczalnego stosunku siły poprzecznej do pionowej);

- emisji dźwięku;

- zużycia kół i szyn.

Wszystkie wymienione zalety odnoszą się do jazdy w łukach torowych kiedy dochodzi do kontaktu pomiędzy obrzeżem koła a główką szyny. W wózku wykorzystano system EasyRail firmy SKF [7] składający się z: czujnika wykrywania zakrętów, zbiornika smaru i dyszy smarującej. Doprowadzone do systemu powietrze z układu pneumatycznego pojazdu, mieszane jest ze smarem, a następnie rozpylane na powierzchni obrzeża. Bezpośredniemu smarowaniu podlega jedynie toczny zestaw kołowy (rys. 17), a pozostały na szynie smar, samoistnie nanoszony jest na obrzeża zestawu napędnego (toczne zestawy kołowe znajduję się zawsze na początku składu).

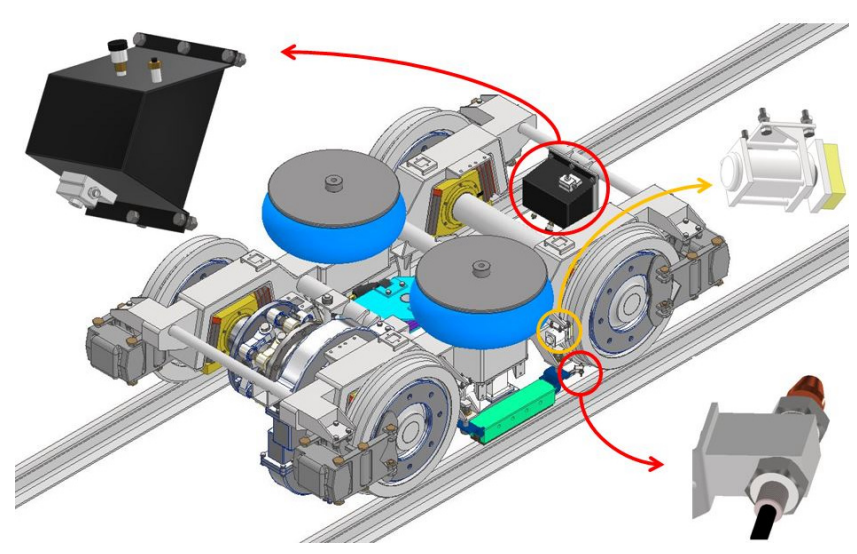

Fig. 17. Components of lubrication and wheel tread cleaning systems [4]

Rys. 17. Rozmieszczenie elementów układów smarowania obrzeży i kondycjonowania powierzchni tocznych [4]

Zmniejszona chropowatość powierzchni tocznych, wynikająca $\mathrm{z}$ zastosowania hamulców tarczowych (brak elementu oczyszczającego je z potencjalnych zanieczyszczeń jak np. klocek hamulcowy hamulca klockowego), skutkuje spadkiem współczynnika przyczepności występującego na styku koło-szyna. W celu przeciwdziałania temu zjawisku zastosowano, przy każdym kole, blok czyszczący (rys. 17), który okresowo jest dociskany do powierzchni tocznych kół. O częstotliwości i sile docisku, decyduje sterownik układu hamulcowego.

\section{PODSUMOWANIE}

W niniejszym artykule poglądowo przedstawiono konstrukcje wózka kolei podwieszanej oraz zastosowane w nim rozwiązania techniczne. W odróżnieniu od pojazdów systemu Eugen Langen, proponowany wózek 
- low mass - short wheelbase (distance between wheelsets which equals 1,6 meter) and internal bogie frame;

- relatively high value of traction effort - two-stage gearbox and asynchronous traction motor (additionally in comparison to direct current motor of the same power, asynchronous motor is smaller);

- good movement parameters in curved track - elastic guidance of wheelsets in bogie frame.

Furthermore, thanks to the use of standard gauge, this bogie construction (without its propulsion system) could be used in conventional suburban rail vehicle. umożliwia symetryczne podwieszenie pudła pojazdu (większa stateczność pojazdu w trakcie ruchu) oraz poprzez podatne prowadzenie zestawów kołowych zwiększa bezpieczeństwo jazdy i zmniejsza zużycie współpracujących elementów (koło-szyna). W stosunku do wózka systemu SAFAGE charakteryzuje się znacznie prostszą konstrukcją dzięki zastosowaniu kolejowych kół stalowych, które zapewniaja prowadzenia pojazdu w torze (brak dodatkowych kół prowadzących), jednocześnie koła w porównaniu do kół ogumionych charakteryzują się niższym zużyciem i oporem ruchu. Ponadto proponowana konstrukcja spełnia wszystkie założenia projektowe pojazdu:

- niska masa własna - krótka baza wózka (odległość pomiędzy osiami wynosi jedynie 1,6 metra) oraz wewnętrzna rama wózka;

- stosunkowo wysoka wartość siły trakcyjnej zastosowanie dwustopniowej przekładni i silnika asynchronicznego (dodatkowo silnik tego typu o zadanej mocy charakteryzuje się mniejszymi gabarytami niż odpowiadający mu silnik prądu stałego);

- dobre właściwości jezdne w łuku torowym - podatne prowadzenie zestawów kołowych.

Co więcej, dzięki zastosowaniu normalnotorowego rozstawu szyn, opisana konstrukcja wózka (po eliminacji układu napędowego), mogłaby zostać wykorzystana w pojeździe szynowym ruchu podmiejskiego.

\section{BIBLIOGRAPHY / BIBLIOGRAFIA}

[1] Kuczyk M., Jędrzejewski P., Załuski P.: The concept of suspended urban rail vehicle. Rail vehicles no 2/2021, pp 5266 https://doi.org/10.53502/RAIL-139982

[2] Kuczyk M., Jędrzejewski P., Załuski P.: Evaluation of suspended rail vehicle movements parameters. Rail vehicles no 3/2021, pp. 20-29. https://doi.org/10.53502/RAIL-143045

[3] Website: https://kamakura-enoshima-monorail.jp/fun/index.html (accessed on: 07.10.2020).

[4] Jędrzejewski P., Kuczyk M.: Koncepcja wagonu silnikowego kolei podwieszanej. Master thesis, Gdańsk 2020.

[5] Christos N. Pyrgidis. 25 Feb 2016, Behaviour of rolling stock on track from: Railway Transportation Systems CRC Press. Accessed on: 26 Dec 2020 https://www.routledgehandbooks.com/doi/10.1201/b19472-4.

[6] Sobaś M.: Stan i doskonalenie kryteriów bezpieczeństwa przed wykolejeniem pojazdów szynowych; Pojazdy Szynowe nr 4/2005, str. 1-13. https://doi.org/10.53502/RAIL-139807

[7] SKF publication: Railway technical handbook, volume 1-axleboxes, wheelset bearings, sensors, condition monitoring, subsystems and services; July 2011. Accessed on: 07.10.2020. https://www.skf.com/binaries/pub12/Images/0901d196801410ca10987_2-EN_tcm_12-503040.pdf

[8] Romaniszyn Z.: Podwozia wózkowe pojazdów szynowych; Wydawnictwo Politechniki Krakowskiej, Kraków 2010

[9] Eukaszewski K.: Contribution to modern methods of wheelset guidance; Rail vehicles, no. 3/2017, pp. 25-32. https://doi.org/10.53502/RAIL-138447

[10] Safety alerts from:19.02.2016 and 10.06.2016. Accessed on: 20.10.2020 https://www.utk.gov.pl/pl/monitorowanie/alerty-bezpieczenstwa/alerty-bezpieczenstwa-o-1/6988,Alerty-bezpieczenstwa -opublikowane-w-2016-roku.html

[11] Centa company catalogue: Pure Power, rail products. Accessed on:07.10.2020. http://www.centa.info/data/content/productIntroRail/382/rail--en-01-12.pdf

[12] Trelleborg product brochure: Air Springs System. Accessed on: 07.10.2020. https://www.trelleborg.com/en/anti-vibration-solutions/products-and-solutions/suspension-products/airspring

[13] Knorr - Bremse product brochure: Magnetic track brakes - light rail vehicles; September 2018. Accessed on: 07.10.2020

https://www.knorrbremse.com/remote/media/documents/railvehicles/product broschures/2018 2/product/brake syste ms/Magnetic_Track_Brakes_-_LRV_P-1269_EN.pdf 